\title{
Hubungan antara beban kerja, besaran upah, dan stres kerja pada karyawan pengelolaan limbah
}

\author{
Sarifa, ${ }^{1}$ Magdalena Wartono ${ }^{2}$
}

\begin{abstract}
ABSTRAK
\section{LATAR BELAKANG}

Perkembangan dunia bisnis yang dinamis tentu berpengaruh terhadap tuntutan produktivitas kerja karyawan. Dalam menjalankan tugas mereka tidak jarang para karyawan mengalami stres kerja yang bisa diakibatkan oleh berbagai faktor antara lain beban kerja dan besaran upah kerja. Tujuan dari penelitian ini adalah untuk mengetahui hubungan antara beban kerja, besaran upah dengan stres kerja pada karyawan perusahaan pengelolaan limbah.
\end{abstract}

\section{METODE}

Studi cross-sectional pada 95 karyawan perusahaan pengelolaan limbah. Data sosiodemografi, lama kerja dan besaran upah dikumpulkan dengan kuesioner. Kategori beban kerja didapatkan dengan menghitung rumus persentase beban kardiovaskuler dan penilaian stres dengan mengunakan survei Health and Safety Executive (HSE). Analisis hubungan antara variabel dilakukan dengan uji Chi-square dan Kolmogorov-smirnov.

\section{HASIL}

Responden paling banyak yang berusia 26-45 tahun (62.1\%) dan didominasi oleh laki-laki (74.7\%). Responden yang telah bekerja $<5$ tahun adalah 55.8\% dan yang sudah menikah sebanyak $69.5 \%$. Sebanyak $78.9 \%$ responden tidak menerima besaran upah yang sesuai dengan Upah Minimum Kota. Dalam hal beban kerja, sebanyak 49 responden termasuk kategori diperlukan perbaikan. Mayoritas responden mengalami stres sedang (72.6\%). Tidak terdapat hubungan bermakna antara beban kerja dan kejadian stres kerja $(\mathrm{p}=0.758)$, dan terdapat hubungan yang bermakna antara upah terhadap stres kerja pada karyawan perusahaan pengelolaan limbah di Karawang $(\mathrm{p}=0.000)$.

\section{KESIMPULAN}

Penelitian menunjukkan banyak karyawan yang mengalami stres dan didapatkan hubungan yang bermakna dengan besara upah tetapi tidak dengan beban kerja. Dengan demikian perusahaan perlu melakukan kajian terhadap sistem perupahan dan manajemen stres di tempat kerja.

Kata kunci: beban kerja, upah, stres kerja, karyawan

\author{
${ }^{1}$ Program Studi Pendidikan Dokter, \\ Fakultas Kedokteran Universitas \\ Trisakti, Indonesia \\ ${ }^{2}$ Departemen Anatomi, Fakultas \\ Kedokteran Universitas Trisakti, \\ Jakarta, Indonesia

\section{Korespondensi:} \\ Magdalena Wartono \\ Departemen Anatomi, Fakultas \\ Kedokteran Universitas Trisakti, \\ Jakarta, Indonesia \\ Jalan Kyai Tapa (Kampus B) \\ Usakti, Grogol, Indonesia 11440 \\ Email: \\ magdalena_w@trisakti.ac.id
}

J Biomedika Kesehat 2021;4(2):70-78 DOI: 10.18051/JBiomedKes.2021. v4.70-78

pISSN: 2621-539X / eISSN: 2621-5470

Artikel akses terbuka (open access) ini didistribusikan di bawah lisensi Creative Commons Attribution 4.0 International (CC-BY 4.0) 


\section{ABSTRACT}

\section{The relationship between workload, wages, and work stress on waste company employees}

\section{BACKGROUND}

This dynamic business world certainly demands higher productivity of employees, therefore in order to achieve the company goals, some employees are exposed to certain risk factors that can lead to stress. The aim of this study was to determine the relationship between workload, wages, and job stress.

\section{METHODS}

A cross-sectional study was conducted involving 95 employees of waste company employees. Sociodemographic data, tenure, and wages were collected using a questionnaire. The workload category was obtained by calculating the percentage of cardiovascular load and job stress assessment was obtained by Health and Safety Executive (HSE) survey. The relationship between variables was analyzed by Chi-square and Kolmogorov-smirnov.

\section{RESULTS}

Most respondents were 26-45 years old (62.1\%) and dominated by men (74.7\%). Respondents who have worked $<5$ years were $55.8 \%$ and $69.5 \%$ were married. As many as $78.9 \%$ of respondents did not receive a proper wage. In terms of workload, 49 respondents were in the category of required repairs. The majority of respondents experienced moderate job stress $(72.6 \%)$. There was no significant relationship between workload and job stress $(p=0.758)$, and there is a significant relationship between wages and job stress $(p=0.000)$.

\section{CONCLUSION}

Research showed that many employees experienced stress, and there was a significant relationship with wages but not with the workload. Thus the company needs to review the wage system and conduct stress management in the workplace.

Keywords: workload, wage, job stress, employee

\section{PENDAHULUAN}

Dunia saat ini sangat dinamis, demikian juga dengan bidang bisnis dan usaha. Dalam hal untuk dapat menghadapi kompetisi yang demikian intens, perusahaan-perusahaan menerapkan berbagai strategi untuk mencapai tujuan organisasi yang tentu saja melibatkan peran dari para karyawan. Mereka diharapkan dapat melakukan pekerjaannya dengan cepat dan efisien. ${ }^{(1)}$

Hal-hal tersebut tentu membuat para karyawan di seluruh dunia menghadapi suatu masalah dalam organisasi yang dinamakan stres. Stres kerja telah menjadi perhatian baik bagi para pengusaha maupun karyawan. Semua karyawan memerlukan stres dalam tingkat tertentu untuk dapat melakukan dan menyelesaikan pekerjaannya. Akan tetapi bila stres tersebut berlebihan dan dalam jangka waktu yang lama akan berefek buruk pada karyawan yang dapat berdampak kepada performa dan efisiensi dari karyawan. ${ }^{(2)}$

Stres kerja adalah suatu kondisi ketegangan yang membuat seseorang karyawan mengalami ketidakseimbangan fisik dan juga psikis yang memengaruhi emosi, proses berpikir, dan kondisinya. Pendapat lain mengatakan bahwa stres kerja adalah perasaan tidak nyaman yang dialami karyawan di mana perasaan ini menimbulkan tekanan pada dirinya dalam menghadapi pekerjaannya. ${ }^{(3)}$

Stres kerja dapat menimbulkan gangguan pada kesehatan fisik, mental dan sosial pekerja. Gangguan kesehatan fisik yang dapat terjadi adalah kelelahan kronis, sakit kepala, hipertensi, penyakit kardiovaskuler, dan keluhan musculoskeletal. Sedangkan distres psikososial yang terjadi dapat berupa kelelahan mental, gangguan mood, gangguan tidur, sulit berkonsentrasi, depresi, kecemasan sampai keinginan untuk bunuh diri. ${ }^{(4)}$

Saat ini, para peneliti mencatat bahwa kerugian akibat stres kerja adalah sangat besar. Beberapa perusahaan di Australia mencatat kerugian sebesar 15 juta dollar, di Amerika sebesar 200 miliar dollar dan di Inggris sebesar 63 miliar poundsterling. Kerugian ini berkaitan dengan dampak dari stres kerja berupa tingkat absen yang tinggi, produktivitas yang rendah, performa yang menurun dan angka pergantian karyawan yang tinggi. ${ }^{(2)}$

Berdasarkan Labour Force Survey (LFS), pada tahun 2015-2016 jumlah total kasus stres kerja, depresi atau cemas adalah sekitar 488.00 kasus dan tingkat prevalensi mencapai 1510 per 100.000 pekerja di Inggris. ${ }^{(5)}$ Selain itu di kawasan Asia Pasifik kejadian stres kerja melebihi ratarata global dengan kisaran $48 \%$. Suatu survei oleh Regus pada tahun 2012 melaporkan bahwa tingkat stres kerja di beberapa negara seperti Malaysia 
mencapai 57\%, Hongkong 62\%, Singapura 63\%, Vietnam 71\%, Tiongkok 73\%, Indonesia 73\%, dan Thailand $75 \%{ }^{(6)}$

Penelitian Dwivira A terhadap 15 pekerja area workshop PT. Star Queen Indonesia mendapatkan pekerja dengan kondisi stres kerja ringan sebesar $6.67 \%$, stres kerja sedang $60 \%$, dan stres kerja berat sebesar $33.33 \%$. $^{(7)}$

Faktor-faktor yang memengaruhi kejadian stres pada karyawan terdiri dari faktor pekerjaan, individual, organisasi, dan lingkungan. Faktor pekerjaan meliputi tugas, tanggung jawab, beban kerja yang berat, beban kerja yang bervariasi, peran yang ambigu, dan konflik peran. Yang termasuk faktor lingkungan adalah kekurangan sumber daya, permasalahan dengan rekan kerja, dan gaya manajemen yang buruk. Sedangkan faktor organisasi mencakup waktu kerja yang panjang, pelatihan yang tidak adekuat, ketidakamanan pekerjaan, upah yang tidak, dan kurangnya prospek karir. Selain itu, faktor individu atau sosiodemografi dari pekerja juga dapat memengaruhi kejadian stres pada pekerja seperti jenis kelamin, tingkat Pendidikan, masa kerja, ras dan kemampuan untuk menghadapi stressor di dalam pekerjaan. ${ }^{(4)}$

Menurut Sunarso beban kerja adalah sekumpulan atau sejumlah kegiatan yang harus diselesaikan oleh suatu unit organisasi atau pemegang jabatan dalam jangka waktu tertentu. Sedangkan Permendagri No. 12/2008 menyatakan bahwa beban kerja adalah besaran pekerjaan yang harus dipikul oleh suatu jabatan/unit organisasi dan merupakan hasil kali antara volume kerja dan norma waktu. ${ }^{(8)}$ Menurut Susilowati, beban kerja terbagi menjadi 2 yaitu beban kerja fisiologis dan beban kerja psikologis. ${ }^{(9)}$

Beban kerja adalah jumlah tugas-tugas yang harus diselesaikan oleh pekerja dalam kurun waktu yang ditentukan. Beban kerja yang muncul bisa dalam bentuk yang bermacam-macam contohnya desakan waktu dalam menyelesaikan pekerjaannya, lamanya waktu kerja, kurangnya waktu istirahat dll. Jika beban kerja ini tidak ditanggulangi, maka akan menimbulkan stres kerja pada pekerja tersebut. Hubungan ini diperkuat dengan adanya hasil penelitian yang dilakukan oleh Zulkifli et al. yang dilakukan di PT Elnusa TBK di mana didapatkan hasil bahwa terdapat hubungan antara beban kerja dan stres kerja pada karyawan di PT tersebut. ${ }^{(10)}$ Penelitian Kokorokoet et al. pada perawat di Ghana juga menyimpulkan bahwa adanya korelasi positif antara beban kerja dengan stres kerja, semakin tinggi beban kerja maka semakin tinggi juga tingkat stres kerja. ${ }^{(11)}$

Selain beban kerja, stres kerja juga berhubungan dengan besaran upah yang diterima oleh pekerja. Menurut Pasal 1 ayat 30 UU No. 13 Tahun 2003 tentang Ketenagakerjaan, upah adalah hak pekerja/buruh yang diterima dan dinyatakan dalam bentuk uang sebagai imbalan dari pengusaha atau pemberi kerja kepada pekerja/ buruh yang ditetapkan dan dibayarkan menurut suatu perjanjian kerja, kesepakatan, atau peraturan perundang-undangan, termasuk tunjangan bagi pekerja/buruh dan keluarganya atas suatu pekerjaan dan/atau jasa yang telah atau akan dilakukan. ${ }^{(12)}$ Seperti halnya hasil dari penelitian yang dilakukan oleh Dhanny yang menunjukkan adanya hubungan antara upah dengan stres kerja pada para penjaga palang pintu rel kereta api di Jember. ${ }^{(13)}$

Akan tetapi Hasbi Ibrahim et al. menyatakan bahwa tidak terdapat hubungan antara beban kerja, upah dengan kejadian stres kerja pada karyawan. Karena jika beban kerja dapat diselesaikan dengan baik serta tepat waktu dan juga upah yang diterima cukup maka stres kerja tidak akan terjadi. ${ }^{(14)}$ Tujuan dari penelitian ini adalah untuk menentukan hubungan antara beban kerja, besasran upah dengan stres kerja pada karyawan perusahaan pengelolaan limbah.

\section{METODE}

Desain penelitian ialah analitik observasional dengan pendekatan cross-sectional. Penelitian ini di lakukan di perusahaan pengelolaan limbah yang berada di daerah Karawang pada bulan Oktober 2020-Desember 2020.

Dari rumus perhitungan sampel jumlah responden yang diperlukan adalah 117 responden, namun saat dilakukan penelitian hanya ada 95 karyawan (81\% dari kebutuhan sampel) yang bersedia untuk menjadi responden dengan rentang usia antara 18-56 tahun dan sebagian besar berjenis kelamin laki-laki. Para karyawan ini telah memenuhi kriteria inklusi yaitu telah bekerja lebih dari tiga bulan dan bersedia menandatangani informed consent serta tidak termasuk dalam kriteria ekslusi yaitu memiliki riwayat gangguan/ 
kelainan kejiwaan berupa depresi atau gangguan bipolar. Data didapatkan melalui wawancara menggunakan kuesioner, dan pengukuran.

Untuk variabel stres kerja diukur dengan menggunakan penilaian Health and Safety Executive (HSE) yang terdiri dari 35 pertanyaan. Di antaranya 23 pertanyaan bersifat positif dan 12 pertanyaan bersifat negatif. Besaran skor tergantung pada jawaban yang dipilih yang merupakan 5 skala likert berupa tidak pernah (0 kali dalam seminggu), jarang (1-2 kali dalam seminggu), agak sering (3-4 kali dalam seminggu), sering (5-6 kali dalam seminggu), dan selalu ( 7 kali dalam seminggu). Untuk pertanyaan yang positif, jawaban selalu mendapatkan skor 5 dan untuk jawaban tidak pernah mendapatkan skor 1, untuk pertanyaan yang negatif berlaku sebaliknya. Total skor dijumlahkan dan kemudian ditentukan kategori stres kerja berdasarkan kisaran skor di Tabel 1. Semua pertanyaan ini telah diuji reliabilitasnya dengan hasil uji reliabilitas menggunakan metode Cronbach's $\alpha=0.63$ (sangat reliabel)..$^{(15)}$

Tabel 1. Kategori stres kerja ${ }^{(15)}$

\begin{tabular}{ll}
\hline Skor & Kategori Stres Kerja \\
\hline $140-175$ & Rendah \\
$105-139$ & Sedang \\
$70-104$ & Tinggi \\
$35-69$ & Sangat Tinggi \\
\hline
\end{tabular}

Sedangkan untuk penilaian tingkat beban kerja fisik dilakukan dengan menghitung denyut nadi saat kerja dan saat istirahat. Denyut nadi istirahat diukur saat responden belum mulai bekerja, sedangkan denyut nadi kerja dihitung setelah responden bekerja selama 2 jam. Untuk denyut nadi maskimum dihitung dengan cara (220-umur) untuk laki-laki dan (200-umur) untuk perempuan. Hasil ketiga denyut nadi ini kemudian dimasukkan ke dalam rumus perhitungan persentase beban kardiovaskuler/Cardiovascular Load (\%CVL). ${ }^{(9)}$

Hasil perhitungan kemudian dikategorikan menurut klasifikasi di tabel berikut:

$\% C V L=\frac{100 \mathrm{x}(\text { denyut nadi kerja }- \text { denyut nadi istirahat })}{\text { Denyut nadi maksimum }- \text { denyut nadi istirahat }}$
Tabel 2. Klasifikasi beban kerja berdasarkan $\% \mathrm{CVL}^{(9)}$

\begin{tabular}{ll}
\hline \%CVL & Klasifikasi \%CVL \\
\hline$<30 \%$ & Tidak terjadi kelelahan \\
$30 \%-59 \%$ & Diperlukan perbaikan \\
$60 \%-79 \%$ & Kerja dalam waktu singkat \\
$80 \%-99 \%$ & Diperlukan tindakan segera \\
$100 \%$ & Tidak diperbolehkan beraktivitas \\
\hline
\end{tabular}

Variabel lainnya seperti besaran upah dan karakteristik sosiodemografi didapatkan dengan wawancara menggunakan kuesioner. Untuk variabel besaran upah, upah karyawan dalam sebulan dikategorikan sebagai sesuai dengan Upah Minimum Kota (UMK) bila lebih atau sama dengan Rp 4.500.000 (sesuai dengan Surat Edaran 561/75/Yanbangsos, Pelaksanaan UMK Kabupaten/Kota di Jabar 2020), bila kurang dari Rp 4.500.000 dimasukkan dalam kategori tidak sesuai dengan UMK.Data hasil penelitian kemudian diolah dengan menggunakan program Statistical Package for Sosial Sciences (SPSS) for windows versi 20.0. Hubungan antara variabel disajikan ke dalam bentuk tabel tabulasi silang dan dianalisis dengan mengunakan uji Chi-square dengan nilai kemaknaan $\mathrm{p}<0.05$. Penelitian ini telah mendapatkan persetujuan dari Komisi Etik Riset Fakultas Kedokteran Universitas Trisakti dengan No: 99/KER-FK/10/2020, Jakarta pada tanggal 20 September 2020.

\section{HASIL}

Penelitianinidilakukanpadaparakaryawan perusahaan pengelolaan limbah di Karawang. Dari 95 karyawan yang bersedia menjadi responden, 59 (62.1\%) berusia di antara 26-45 tahun, sebagian dari mereka berjenis kelamin laki-laki (74.7\%) dan telah menikah (69.5\%). Terkait dengan masa kerja, karyawan yang bekerja lebih dan sama dengan 5 tahun $(44.2 \%)$ lebih sedikit dibanding dengan yang bekerja kurang dari 5 tahun (55.8\%). Dari hasil wawancara diperoleh data bahwa 78.9\% karyawan menerima upah di bawah Upah Minimum Karyawan kabupaten/kota Jawa Barat 2020. Lebih dari setengah responden-responden yang persentase beban kerja kardiovaskulernya berada di atas kategori yang diperlukan perbaikan (lihat Tabel 3), di samping itu ada sebanyak $72.6 \%$ responden mengalami stres sedang. 
Tabel 3. Distribusi frekuensi karakteristik sosiodemografi, lama kerja, beban kerja dan stres kerja

\begin{tabular}{|c|c|c|}
\hline Karakteristik $(\mathrm{n}=95)$ & (n) & $(\%)$ \\
\hline \multicolumn{3}{|l|}{ Usia } \\
\hline$<25$ tahun & 20 & 21.1 \\
\hline 26-45 tahun & 59 & 62.1 \\
\hline 46-55 tahun & 26 & 16.8 \\
\hline \multicolumn{3}{|l|}{ Jenis Kelamin } \\
\hline Laki-Laki & 71 & 74.7 \\
\hline Perempuan & 24 & 25.3 \\
\hline $\begin{array}{l}\text { Status Pernikahan } \\
\text { Belum Menikah }\end{array}$ & 28 & 29.5 \\
\hline Duda & 1 & 1.1 \\
\hline Menikah & 66 & 69.5 \\
\hline \multicolumn{3}{|l|}{ Lama Kerja } \\
\hline$<5$ tahun & 53 & 55.8 \\
\hline$\geq 5$ tahun & 42 & 44.2 \\
\hline \multicolumn{3}{|l|}{ Upah } \\
\hline Sesuai UMK ( $\geq 4,5$ Juta) & 20 & 21.1 \\
\hline Tidak Sesuai UMK (<4,5 Juta) & 75 & 78.9 \\
\hline \multicolumn{3}{|l|}{ Beban Kerja } \\
\hline Tidak Terjadi Kelelahan & 46 & 48.4 \\
\hline Diperlukan Perbaikan & 47 & 49.5 \\
\hline Kerja Dalam Waktu Singkat & 1 & 1.1 \\
\hline Diperlukan Tindakan & 1 & 1.1 \\
\hline \multicolumn{3}{|l|}{ Stres Kerja } \\
\hline Rendah & 12 & 12.6 \\
\hline Sedang & 69 & 72.6 \\
\hline Tinggi & 14 & 14.7 \\
\hline
\end{tabular}

Analisis bivariat penelitian ini adalah untuk menentukan hubungan antara variabel bebas yaitu beban kerja, besaran upah dengan variabel tergantung stres kerja pada karyawan perusahaan pengelolaan limbah.

Saat melakukan analisis bivariat, masing-masing satu responden yang beban kardiovaskulernya $(\% \mathrm{CVL})$ masuk ke dalam kategori kerja dalam waktu singkat dan diperlukan tindakan digabung ke dalam kategori diperlukan perbaikan, sehingga menjadi total 49 responden. Dari 49 responden ini 37 orang $(75.5 \%)$ di antaranya mengalami stres kerja sedang, angka ini hanya sedikit lebih tinggi dibandingkan dengan responden yang tidak mengalami kelelahan (69.6\%). Sedangkan untuk kategori stres tinggi, para responden yang tidak mengalami kelelahan sedikit lebih banyak yang mengalami stres kerja tinggi (17.4\%) dibandingkan kelompok yang diperlukan perbaikan dan lain-lain (12.2\%). Hasil uji Chi-square dengan penggabungan sel didapatkan nilai $\mathrm{p}=0.758(\mathrm{p}>0.05)$, artinya tidak didapatkan hubungan yang bermakna antara beban kerja dengan kejadian stres kerja pada karyawan perusahaan pengelolaan limbah di Karawang.

Di antara responden yang mendapatkan upah di bawah UMK, yang mengalami stres sedang lebih banyak dari responden yang mendapatkan upah sesuai UMK. Akan tetapi responden yang mendapatkan upah sesuai UMK lebih banyak yang mengalami stres tinggi dibandingkan dengan yang mendapatkan upah di bawah UMK $(20 \%$ vs 13.3\%). Hasil uji bivariat dengan uji Chi-square tidak memenuhi syarat, sehingga digunakan uji Kolmogorov-smirnov dan diperoleh nilai $\mathrm{p}=0.000$ di mana nilai $\mathrm{p}<0.05$, artinya di dapatkan hubungan yang bermakna antara besaran upah dengan stres kerja pada karyawan perusahaan pengelolaan limbah di Karawang.

\section{PEMBAHASAN}

Hasil penelitian menunjukkan rentang usia karyawan yang terbanyak adalah di rentang 26-40 tahun (51.60\%). Rozman et al. melakukan survei terhadap 619 karyawan di perusahaan sedang dan besar di Slovenia menyimpulkan bahwa tingkat stres kerja lebih rendah pada grup karyawan yang lebih tua ( $>50$ tahun) dibandingkan dengan grup yang berusia lebih muda. ${ }^{(16)} \mathrm{Hal}$ ini menurut Adam et al. para karyawan yang berusia lebih tua mempunyai pengalaman kerja yang lebih banyak, mereka telah memiliki berbagai pengetahuan dan keahlian dalam pekerjaan sehingga telah memiliki modal untuk menghadapi stressor yang berkaitan dengan pekerjaan. ${ }^{(17)}$

Karyawan yang berjenis kelamin lakilaki lebih banyak dibandingkan perempuan, yaitu sebanyak 71 orang (74.7\%). Mosadeghrad melaporkan bahwa lebih banyak karyawan perempuan di rumah sakit di Iran yang mengalami stres kerja dibandingkan karyawan laki-laki. Perempuan selain memiliki tanggung jawab di pekerjaan juga memiliki tanggung jawab di rumah, sehingga mereka mengalami stres ganda. Stresor antara laki-laki dan perempuan itu berbeda. Pada laki-laki stres lebih dikarenakan oleh upah yang tidak cukup, sedangkan perempuan lebih karena diskriminasi di tempat kerja, beban 
Tabel 4. Hubungan beban kerja, besaran upah dan stres kerja

\begin{tabular}{|c|c|c|c|c|c|c|c|}
\hline \multirow{3}{*}{ Karakteristik } & \multicolumn{6}{|c|}{ Stres Kerja } & \multirow{3}{*}{ Nilai $\mathrm{p}^{*}$} \\
\hline & \multicolumn{2}{|c|}{ Rendah } & \multicolumn{2}{|c|}{ Sedang } & \multicolumn{2}{|c|}{ Tinggi } & \\
\hline & $\mathrm{n}$ & $\%$ & $\mathrm{n}$ & $\%$ & $\mathrm{n}$ & $\%$ & \\
\hline \multicolumn{8}{|l|}{ Beban Kerja } \\
\hline Tidak Terjadi Kelelahan & 6 & 13.0 & 32 & 69.6 & 8 & 17.4 & \multirow{2}{*}{$0.758 *$} \\
\hline Diperlukan Perbaikan & 6 & 12.2 & 37 & 75.5 & 6 & 12.2 & \\
\hline \multicolumn{8}{|l|}{ Besaran Upah } \\
\hline Sesuai UMK & 4 & 20.0 & 12 & 60.0 & 4 & 20.0 & \multirow{2}{*}{$0.000^{\#}$} \\
\hline Tidak Sesuai UMK & 8 & 10.7 & 57 & 76.0 & 10 & 13.3 & \\
\hline
\end{tabular}

$\mathrm{n}=$ jumlah; \%=persentase; *Uji Chi-Square, ${ }^{*} \mathrm{Uji}$ Kolmogorov-smirnov

kerja yang terlalu banyak, dan kurangnya jam istirahat. Walaupun karyawan perempuan lebih banyak yang mengalami stres, namun menurut Mosadeghrad, karyawan laki-laki lebih banyak yang menggunakan hari cuti terkait dengan stres dibandingkan perempuan (sembilan vs tujuh hari per tahun). ${ }^{(4)}$

Berdasarkan lama kerja dari total 95 karyawan, jumlah karyawan bekerja $<5$ tahun (55.8\%) lebih banyak dibandingkan yang lebih atau sama dengan 5 tahun (44.2\%). Suatu penelitian terhadap para manajer di Pendidikan Tinggi menunjukkan bahwa kelompok manajer yang bekerja 5 tahun atau kurang memiliki tingkat stres yang tinggi sedangkan mereka yang sudah bekerja selama 11-15 tahun menunjukkan tingkat stres yang lebih rendah dibandingkan kelompok lainnya. Hal ini menunjukkan bahwa karyawan yang telah bekerja lebih lama memiliki lebih banyak pengalaman kerja, mengetahui cara atau taktik tertentu untuk menghadapi stres yang berkaitan dengan komitmen personal maupun profesional secara efektif dan juga mereka telah ahli dalam menyelesaikan tugas-tugas mereka secara efektif, sehingga tidak menimbulkan kelelahan kerja. ${ }^{(18)}$

Para karyawan lebih banyak yang telah menikah yaitu sebanyak 66 orang $(69.5 \%)$. Status pernikahan memang biasanya berpengaruh bagi seseorang, karena apabila seseorang sudah memiliki keluarga maka tanggung jawab dan kewajibannya tidak hanya pada dirinya sendiri tetapi juga pada keluarganya. Seseorang yang sudah menikah pasti mempunyai beban yang lebih berat daripada yang belum menikah. Hal tersebut disebabkan karena orang yang sudah menikah tidak hanya memikirkan kebutuhan diri sendiri, tetapi juga memikirkan kebutuhan keluarganya sehingga orang yang sudah menikah cenderung mempunyai tingkat stres yang lebih tinggi. ${ }^{(19)}$

Sebanyak 75 orang $(78.9 \%)$ dari 95 responden tidak mendapatkan bayaran upah sesuai dengan UMK. Masalah seperti ini juga dihadapi oleh para pekerja di $60 \%$ perusahaan yang berada di Semarang. ${ }^{(20)}$

Lebih dari separuh $(51.6 \%)$ responden terutama yang bekerja di bagian produksi meliputi bagian peleburan dan bagian elektrokoagulan memiliki beban kerja yang mengakibatkan persentase cardiovascular (\%CVL) kategori diperlukan perbaikan dan lain-lain. Hal ini menunjukkan beban kerja fisik yang cukup tinggi dan perlu dilakukan pengendalian terhadap beban kerja karyawan. Penemuan ini selaras dengan penelitian yang dilakukan Handika et al. yang mendapatkan 6 dari 10 operator produksi mengalami kelelahan fisik yang memerlukan tindakan perbaikan. ${ }^{(21)}$

Para responden penelitian ini banyak yang mengalami stres kerja dan sebagian besar ada di tingkat sedang yaitu sebesar $72.6 \%$. Sebuah penelitian oleh Widyastuti terhadap pekerja konstruksi truk juga mendapatkan $60 \%$ pekerja mengalami stres sedang. Di perusahaan ini terdapat beberapa faktor risiko yang mungkin dapat menimbulkan terjadinya stres kerja seperti besaran upah yang tidak sesuai dengan UMK, lebih banyak yang berusia muda dan masa kerja kurang dari 5 tahun..$^{(7)}$

Dari hasil analisis bivariat antara beban kerja fisik dengan stres kerja menunjukkan bahwa baik pada responden yang termasuk kategori tidak terjadi kelelahan dengan mereka yang masuk ke kategori diperlukan perbaikan dan lain-lain, 
persentase kejadian stres ringan, sedang maupun berat hanya sedikit berbeda. Hasil analisis bivariat menunjukkan tidak terdapat hubungan bermakna antara beban kerja fisik dengan kejadian stres kerja pada karyawan perusahaan pengelolaan limbah di Karawang. Beban kerja yang berlebih akan mengakibatkan terjadinya kelelahan kerja pada karyawan sehingga berdampak terhadap performa kerja dan produktivitas mereka. Bila produktivitas mereka menurun, maka mereka tidak akan dapat menyelesaikan beban tugas. Hal ini pada akhirnya akan menimbulkan stres kerja pada karyawan. ${ }^{(22)}$

Walaupun dalam hal beban kerja fisik lebih banyak yang masuk ke kategori diperlukan perbaikan dan lain-lain namun beban kerja tersebut dapat diterima dan dijalankan oleh para karyawan dengan baik dan karyawan di perusahaan tersebut dapat beristirahat sejenak sesuai keinginannya, jika mereka merasa lelah sehingga tidak menimbulkan kelelahan berlebihan. Ibrahim et al. juga menyebutkan tidak ada hubungan bermakna antara beban kerja dengan stres kerja pada karyawan di perusahaan penghasil furnitur di Makassar. Beban kerja yang dirasakan para penghasil furnitur ini dirasakan bukan sebagai masalah karena mereka memiliki waktu jeda sekitar 2-3 menit saat merasakan lelah untuk memperoleh kembali tenaga untuk bekerja. (14)

Sedangkan penelitian yang dilakukan oleh Sudiarditha et al. terhadap pegawai negeri sipil di Unit Pelayanan Terpadu menyatakan adanya korelasi positif antara beban kerja fisik dengan stres kerja. Hal ini dikarenakan pegawai di unit tersebut seringkali harus mengerjakan pekerjaanpekerjaan di luar tugas utamanya demi melayani masyarakat yang jumlahnya jauh lebih banyak daripada jumlah pegawai yang ada di unit tersebut. (23) Kejadian seperti ini tidak terjadi di perusahaan limbah di Karawang, tiap-tiap karyawan telah memiliki job desk yang jelas.

Berdasarkan hasil penelitian, responden lebih banyak menerima upah yang tidak sesuai dengan UMK. Responden yang menerima upah tidak sesuai UMK lebih banyak yang mengalami stres sedang (76\%) dibandingkan yang dengan yang sesuai (60\%). Akan tetapi jumlah responden yang menerima upah yang sesuai UMK lebih banyak yang mengalami stres tinggi dibandingkan mereka yang menerima upah di bawah UMK dengan hasil analisis bivariat dinyatakan adanya hubungan yang bermakna antara besaran upah dengan stres kerja pada karyawan perusahaan pengelolaan limbah di Karawang. Hasil ini tidak sejalan dengan hasil penelitian oleh Caron J et al. terhadap penduduk yang berusia 15 tahun dan lebih di Canada di mana persentase kejadian stres lebih tinggi pada mereka yang berpendapatan rendah (28\%) dibandingkan dengan yang berpendapatan tidak rendah (19\%). ${ }^{(24)}$ Demikian juga dengan penelitian oleh Dhanny pada penjaga palang pintu rel kereta api di Jember yang mendapatkan adanya korelasi negatif antara besaran upah dengan tingkat stres $(r=0.384 ; p=0.012)$ yang berarti semakin rendah upah yang diterima maka semakin tinggi tingkat stres pekerja dan sebaliknya. ${ }^{(13)}$

Sebaliknya hasil penelitian ini sesuai dengan penelitian di Amerika yang menunjukkan bahwa karyawan dengan pendapatan tinggi melaporkan lebih tidak bahagia saat bekerja dan merasa lebih stres dibandingkan dengan mereka yang berpendapatan rendah, hal ini karena mereka yang berpendapatan tinggi cenderung memiliki tuntutan pekerjaan yang lebih tinggi dan seringkali harus bekerja di luar jadwal kerja. ${ }^{(25,26)}$ Upah para karyawan perusahaan limbah ini sangat bervariasi, mulai dari Rp. 1.000.000-Rp. 5.500.000 tergantung dari bagian atau departemennya, kinerjanya, lama bekerja serta tingkat kehadiran. Karyawan yang menerima upah yang sesuai atau lebih tinggi dari UMK adalah mereka yang bekerja sebagai mandor dan juga staf kantor yang memiliki tanggung jawab pekerjaan yang lebih tinggi dan jam kerja yang lebih ketat.

Terdapat keterbatasan dalam penelitian ini, yaitu rancangan penelitian yang digunakan adalah potong silang yang tidak dapat menjelaskan adanya hubungan sebab akibat. Selain itu pada penelitian ini tidak mengukur faktor-faktor lain yang dapat menyebabkan kejadian stres kerja yang lain seperti konten pekerjaan, jam kerja, partisipasi dan kontrol, pengembangan karir, hubungan interpersonal, budaya organisasi, dan keseimbangan antara pekerjaan dan kehidupan yang mungkin saja dapat memengaruhi kejadian stres pada karyawan di perusahaan pengelolaan limbah ini. 


\section{KESIMPULAN}

Prevalensi stres kerja pada para karyawan di perusahaan pengelolaan limbah ini termasuk tinggi- Lebih dari separuh karyawan memiliki beban kerja yang memerlukan perbaikan tetapi tidak didapatkan hubungan yang bermakna antara beban kerja dengan stres kerja. Banyak karyawan yang memiliki besaran upah yang tidak sesuai namun mereka yang mendapatkan upah yang sesuai UMK yang lebih banyak mengalami stres tinggi. Dengan demikian disarankan agar perusahaan dapat menerapkan situasi kerja yang kondusif baik dalam hal isi kerja dan konteks kerja terutama dalam hal pengupahan. Selain itu perlu adanya manajemen pengelolaan stres kerja di perusahaan dengan bantuan dari ahli bidang kedokteran kerja, sehingga dapat menurunkan tingkat stres kerja pada pekerja sehingga kesejahteraan dan produktivitas karyawan dapat meningkat.

\section{UCAPAN TERIMA KASIH}

Pihak PT. HBSP Karawang

\section{KONFLIK KEPENTINGAN}

Penulis menyatakan tidak ada konflik kepentingan

\section{REFERENSI}

1. Hassan M, Azmat U, Sarwar S, et al. Impact of Job Satisfaction, Job Stress And Motivation on Job Performance: A Case From Private University of Karachi. Kuwait Chapter of Arabian J. Busi. Manag. Review. 2020;9(2):31-41.

2. Ahmad A, Afgan S. The Relationship of Job Stress and Turnover Intention in Commercial Banks of Pakistan by Assessing the Mediating Role of Burnout. Journal of Business Strategies (Karachi). 2016 06;10(1):1-23.

3. Ningsih DS, Chairizal TN. Pengaruh Stres dan Kepuasan Kerja terhadap Kinerja Perawat Rumah Sakit Ibu dan Anak Eria Bunda Pekanbaru. JOM FEKON [Internet]. 2014;1(2):5-6. Available: https://jom.unri.ac.id/index.php/JOMFEKON/ article/view/5440

4. Mosadeghrad MA. Occupational stress and its consequences. Leadership in Health Services. 2014;27(3):224-239. doi: 10.1108/LHS-07-20130032

5. Kenwa MML, Wiranandha IM, Asthuta AR. Hubungan Kebisingan Dengan Tingkat Stres Kerja Pada Pekerja Bengkel Motor dan Dealer Dwijati Motor Denpasar. E-Jurnal Medika Udayana [Internet]. 2019;8(5). Available from: https://ojs. unud.ac.id/index.php/eum/article/view/51670

6. Habibi J, Jefri. Analisis Faktor Risiko Stres Kerja Pada Pekerja Di Unit Produksi PT. Borneo Melintang Buana Export. Journal of Nursing and Public Health. 2018;6(2):50-9. doi: 10.37676/ jnph.v6i2.658

7. Widyastuti AD. Hubungan Stres Kerja Dengan Kelelahan Kerja Pada Pekerja Area Workshop Konstruksi Box Truck. The Indonesian Journal of Occupational Safety and Health. 2017;6(2):21624. doi: 10.20473/ijosh.v6i2.2017.216-224

8. Rolos JK, Sambul SA, Rumawas W. Pengaruh Beban Kerja Terhadap Kinerja Karyawan pada PT. Asuransi Jiwasraya Cabang Manado Kota. Jurnal Administrasi Bisnis [Internet]. 2018;6(004):19-27. Available from: https://ejournal.unsrat.ac.id/index. $\mathrm{php} / \mathrm{jab} / \mathrm{article} / \mathrm{view} / 21074$

9. Fithri P, Anisa WF. Pengukuran Beban Kerja Psikologis dan Fisiologis Pekerja di Industri Tekstil. Jurnal Optimasi Sistem Industri. 2017;16(2):12030. doi: 10.25077/josi.v16.n2.p120-130.2017

10. Zulkifli, Rahayu ST, Akbar SA. Hubungan Usia, Masa Kerja dan Beban Kerja Dengan Stres Kerja Pada Karyawan Service Well Company PT. ELNUSA TBK Wilayah Muara Badak. KESMAS UWIGAMA: Jurnal Kesehatan Masyarakat. 2019;5(1):46-61. doi: 10.24903/kujkm.v5i1.831

11. Kokoroko E, Sanda MA. Effect of workload on job stress of Ghanaian OPD nurses: the role of coworker support. Saf Health Work. 2019;10(3):341-6. https://doi.org/10.1016/j.shaw.2019.04.002.

12. Undang-Undang Nomor 13 tahun 2003 tentang Ketenagakerjaan [Internet]. Jakarta: 2003. Available from: https://www.hukumonline.com/ pusatdata/detail/13146/undangundang-nomor-13tahun-2003

13. Prasetya DI, Ma'rufi I, Indrayani R. Determinan Stres Kerja Pada Penjaga Palang Pintu Rel Kereta Api Resmi Resort 9.6 Daerah Operasi IX Di Kabupaten Jember. Jurnal Kesehatan. 2019;6(2):76-82. doi: 10.25047/j-kes.v6i2.13

14. Ibrahim H, Amansyah M, Yahya GN. FaktorFaktor yang Berhubungan Dengan Stres Kerja Pada Pekerja Factory 2 PT. Maruki Internasional Indonesia Makassar Tahun 2016. Al-sihah: The Public Health Science Journal [Internet]. 2016;8(1):60-68 Available from: http://journal. uin-alauddin.ac.id/index.php/Al-Sihah/article/ view/2017

15. Tarwaka. Ergonomi Industri Dasar-Dasar Pengetahuan Ergonomi dan Aplikasi di Tempat kerja. 2nd ed. Surakarta: Harapan Press; 2015.

16. Rožman M, Grinkevich A, Tominc P. Occupational Stress, Symptoms of Burnout in the Workplace and Work Satisfaction of the Age-diverse Employees. Organizacija. 2019;52(1):46-52. Available from:http://organizacija.fov.uni-mb.si/index.php/ organizacija/article/view/930

17. Adams GA, DeArmond S, Jex SM, et al. Older Workers, Occupational Stress and Safety. In: Field J, Burke RJ, Cooper CL, editors. SAGE Handbook of Aging, Work and Society. London: SAGE Publications; 2013.

18. Mahmood A, Zamir S, Ain QU, et al. Impact of Age and Level of Experience on Occupational Stress of Academic Managers at Higher Education Level. Mediterranean Journal of Social Sciences [Internet]. 2013;4(1):535-541. Available from: https://www.richtmann.org/journal/index.php/ mjss/article/view/11616

19. Suci ISM. Analisis Hubungan Faktor Individu dan Beban Kerja Mental Dengan Stres Kerja. The Indonesian Journal of Occupational Safety and Health. 2018;7(2):220-229. doi: 10.20473/ijosh. v7i2.2018.220-229 
20. Kirti HN, Priyono J. Mendapat Bayaran Dibawah Ketentuan Upah minimum Regional (UMR). Notarius: Jurnal Studi Kenotariatan [Internet]. 2018;11(1):68-84. Available from: https:// ejournal.undip.ac.id/index.php/notarius/article/ download/23126/15083

21. Handika FS, Yuslistyari EI, Hidayatullah M. Analisis Beban Kerja Fisik dan Mental Operator Produksi di PD. Mitra Sari. Jurnal InTent. 2020;3(2):82-89. Available from: https:/ejournal. lppm-unbaja.ac.id/index.php/intent/article/ view/953

22. Dewi RS, Riana IG. The Effect of Workload on Role Stress and Burnout. JOMA [Internet]. 2019;3(3):15. Available from: http://www.kemalapublisher. com/index.php/JoMA/article/view/274

23. Sudiarditha R, Mardi IK, Margaretha L. (2019). Study of Employee Performance: Workload on Job Satisfaction and Work Stress. Jurnal Ilmiah Econosains [Internet]. 2019;17(1):31-40. Available from: http://journal.unj.ac.id/unj/index. php/econosains/article/view/12696

24. Caron J, Liu A. Factors associated with psychological distress in the Canadian population: a comparison of low-income and non lowincome sub-groups. Community Ment Health J. 2011;47(3):318-30. doi: 10.1007/s10597-0109306-4.

25. Damaske S, Zawadzki MJ, Smyth JM. Stress at work: Differential experiences of high versus low SES workers. Soc Sci Med. 2016;156:125-33. doi: 10.1016/j.socscimed.2016.03.010.

26. Moen P, Lam J, Ammons S, Kelly EL. Time Work by Overworked Professionals: Strategies in Response to the Stress of Higher Status. Work Occup. 2013;40(2):79-114. doi: $10.1177 / 0730888413481482$ 